\title{
The uncertainties of synthetic unit hydrographs applied for basins with different runoff generation processes
}

\section{Incertezas de hidrogramas unitários sintéticos aplicados a bacias com diferentes processos de geração de escoamento}

\author{
Andreia Pedroso $^{1}$ (D) \& Michael Mannich ${ }^{1}$ (D) \\ ${ }^{1}$ Universidade Federal do Paraná, Curitiba, PR, Brasil \\ E-mails: pedroso.ea@gmail.com (AP),mannich@ufpr.br (MM)
}

Received: June 19, 2021 - Revised: October 17, 2021 - Accepted: October 18, 2021

\begin{abstract}
Synthetic unit hydrographs (SUH) are useful tools for the estimation of maximum flows in basins lacking historical records of measurements. However, these methods have many uncertainties and do not always produce results consistent with reality. This study comparatively analyzed the uncertainty of the application of the Snyder, SCS, and Clark HUS methods, widely used, in relation to the observed hydrographs, in the Pequeno River and the Espingarda River basins, located in the State of Paraná, considered small from the point of view of the drainage area. The simulation was performed using the HEC-HMS 4.2.1 software considering a combination of parameters that produced the higher and lower peak flow, respectively named as conservative and bold approaches. It was verified that the SUH methods, in general, overestimated the peak flows for both basins under study. In addition, the results obtained showed that SUH are fundamentally conservative models so that a bold approach in estimating the parameters input leads to results with smaller errors in simulated peak flows. Even running the SUH with the real excess rainfall as input there is an overestimation of the peak flow. SCS SUH produced the highest peak flows and consequently the largest errors while Snyder's SUH produced the smallest errors. The magnitude of the overestimation of the peak flow for the Pequeno River was up to 60 folds. Its geology features suggest a Dunnian runoff generation process, which explains the larger errors.
\end{abstract}

Keywords: SUH methods; Small basins; Dunnian runoff generation; Hortonian runoff generation; SCS-CN method.

\section{RESUMO}

Os hidrogramas unitários sintéticos (HUS) são ferramentas de grande utilidade para a estimativa de vazões máximas em bacias hidrográficas desprovidas de registros históricos de medições. Entretanto, esses métodos possuem muitas incertezas e nem sempre produzem resultados compatíveis com a realidade. Este estudo analisou comparativamente a incerteza da aplicação dos métodos de HUS de Snyder, SCS e Clark, largamente utilizados, em relação aos hidrogramas observados, nas bacias hidrográficas do rio Pequeno e do rio Espingarda, localizadas no estado do Paraná, consideradas pequenas do ponto de vista de área de drenagem. A simulação foi realizada por meio do software HEC-HMS 4.2.1 considerando uma combinação de parâmetros que produziram a maior a menor vazão de pico, denominadas respectivamente abordagens conservadora e arrojada. Constatou-se que os três métodos de HUS analisados, geralmente, superestimaram as vazões de pico para ambas as bacias hidrográficas em estudo. Adicionalmente, os resultados obtidos mostraram que os HUS são fundamentalmente modelos conservadores, de modo que uma abordagem arrojada na estimativa dos parâmetros de entrada conduz a resultados com menores erros nas vazões de pico simuladas. Mesmo simulando HUS com o excesso de chuva real como entrada, há uma superestimativa da vazão de pico. O HUS do SCS produziu as maiores vazões de pico e, consequentemente, os maiores erros, enquanto o HUS de Snyder produziu os menores erros. Para o rio Pequeno, a estimativa chegou a ser 60 vezes superior às medições. As características geológicas sugerem o processo Duniano de geração de escoamento superficial, que explica a magnitude dos erros.

Palavras-chave: Métodos de HUS; Pequenas bacias hidrográficas; Escoamento Duniano; Escoamento Hortoniano; Método do SCS-CN. 


\section{INTRODUCTION}

In water resources planning and management the peak flows are related to risks, security, economic optimization, and structures design. According to Tucci (1998), unfortunately a hydrometeorological network will not cover all locations or has a historical record for the statistical analysis of peak flows. The ungauged basins are often basins with small drainage areas.

This gap can be filled with hydrological models of rainfallrunoff models. One kind of those models is the Synthetic Unit Hydrograph (SUH), defined as the runoff resulting from one unit of excess rainfall, considering it uniformly distributed over the basin (Bras, 1990).

Although SUH is a simple and practical model to be applied for many hydrological studies (Silveira, 2016), it can be inadequate for ungauged basin due to their high uncertainties (Hrachowitz et al., 2013).

Several studies (Hoffmeister \& Weisman, 1977; Tucci, 1998; Cunha et al., 2015; Singh et al., 2014; Zakizadeh \& Malekinezhad, 2015; Thorvat \& Patel, 2016), reported an overall overestimation of the peak flow, up to $100 \%$ (Thorvat \& Patel, 2016). Even been conservative as a design flow, in small basins the costs of structures oversizing can make them impracticable. According to Bhunya et al. (2011), the advantage obtained by the simplicity of its use is opposed to the uncertainties related to the results, making the applicability and acceptance questionable. Farther, Silveira (2016) highlights the need for greater caution when applying the SUH defined empirically, whose results are sensitive to small variations in the parameters.

Singh et al. (2014) classified SUH methods into four groups: a) traditional; b) conceptual; c) probabilistic and d) geomorphological. Traditional models (a) are based on empirical equations, whose coefficients vary over a wide range of values. Conceptual models (b) are based on the continuity equation and linear storage. Probabilistic models (c) use a parametric approach and apply probability density functions to derive SUH. Finally, geomorphological models (d) use the geomorphological characteristics of river basins to develop instantaneous unit hydrographs (IUH).

Since Snyder's first SUH from 1938, new models were developed and modified. However, the robustness and practicality of applying traditional and conceptual SUH, such as Snyder, SCS, and Clark, make them widely used. Under this perspective, several Brazilian agencies (e.g., DNIT, DER, ELETROBRÁS, Sanepar, City Halls) recommend in their hydrological related manuals and handbooks the use of these methods, together with the CN method of excess rainfall (Schechi et al., 2013), for the estimation of design flows.

Hydrological models face uncertainties from input data and from the model itself (Hrachowitz et al., 2013; Wagener et al., 2004). Uncertainties from input data can be reduced by consistency analysis. The uncertainties of the parameters and the inadequacies of the model must be known. Brunner et al. (2018) quantified the various sources of uncertainty in SUH, from the selection of sample data to the final total uncertainty, passing through the stages of construction of the synthetic hydrograph and regionalization to other locations. The uncertainties in the peak flow were $25 \%, 40 \%$, and $50 \%$, respectively for the construction of the hydrographs, regionalization, and total.
Considering the uncertainty of semi-distributed and concentrated modeling, Steinmetz et al. (2019) explored it with SCS and Clark SUH in a $120 \mathrm{~km}^{2}$ area basin in Brazil. The errors in the concentrated model were up to $137 \%$ and $85 \%$, respectively for SCS and Clark methods. The semi-distributed results were even worst with errors up to 594\% and 103\%, respectively. Furthermore, Steinmetz et al. (2019) found that the peaks of the simulated hydrographs were anticipated, indicating that the estimation of the model parameters was also a source of uncertainty in the results.

As with most hydrological rainfall-runoff models (Loewen \& Pinheiro, 2017), SUH are indicated for areas with fast runoff generation in which flow generation processes are based on Hortonian concept. It is important to know and discuss the possible additional errors in cases where the principles of SUH are disregarded (Schulz et al., 2018), even though this hydrological process may not be known previously.

The paper's objective is to highlight the errors of SUH applications for two small basins with different runoff process generation in the State of Paraná, Southern Brazil. We compare errors of Snyder, SCS and Clark SUH methods for some return periods and two methods of estimating effective rainfall.

The broader context of this research is to highlight the range of uncertainties in applying SUH with extreme parameters set up, so that within the empirically possible range we studied these parameters' combinations effect, stated as bold and conservative approaches. Simulations were based on methods established in the literature with estimated parameters also based on the literature. Hydrological data from conventional gauge stations in Brazil were used, where river water levels are taken at 7 am and $5 \mathrm{pm}$. These are the most used for hydrological studies of engineering projects. The errors were computed for the peak flow, which is one of the main variables for hydraulic design and sizing. The results are directly applicable for solutions to water engineering problems.

\section{METHODS AND HYDROLOGICAL DATA PROCESSING}

Two basins, as presented in Table 1, were chosen based on gauge stations from the National Water and Sanitation Agency of Brazil (ANA) database. These basins meet the selection criteria of drainage area less than $250 \mathrm{~km}^{2}$ and more than 50 years of continuous data. The drainage area criteria were based on Raudkivi (1979) recommendations for small basins and suitable for SUH methods applications. A long dataset was required to evaluate peak flows with higher flood return periods typically associated to design flows. Table 2 shows a synthesis of the available gauge stations data in the State of Paraná.

From the rain gauge stations from ANA dataset we selected those close to the basins (Table 1), based on Thiessen polygons method, and that covered the entire flow data period. Figure 1 shows the geographical location of the basins at gauge stations section and the rain gauge stations selected.

Regarding the runoff characteristics, Schechi et al. (2013) verified that the Pequeno River basin has high storage potential due to its geographical relief and soil attributes, expecting to occur flow by saturation, produced by the increase of the phreatic level that emerges and seeps over the surface - Dunne runoff (Schultz, 
Table 1. Selected gauges for each basin.

\begin{tabular}{cccc}
\hline Basin & Area $^{\mathbf{1}}\left[\mathrm{km}^{2}\right]$ & Related gauges & Data size \\
\hline Pequeno River & 105 & Fazendinha (65010000) & $28 / 01 / 1955$ \\
& & & $31 / 12 / 2014$ \\
& & & $01 / 01 / 1982$ \\
& & $31 / 12 / 2016$ \\
& & & $01 / 09 / 1916$ \\
& & Mananciais da Serra (2548041) & $31 / 12 / 2015$ \\
Espingarda River & \multirow{2}{*}{65} & Porto Vitória (65365000) & $19 / 11 / 1945$ \\
& & & $31 / 12 / 2014$ \\
& & & $01 / 03 / 1956$ \\
& & & $01 / 08 / 2007$ \\
\hline
\end{tabular}

${ }^{1}$ At the gauge station section.

Table 2. Data availability of ANA database in the State of Paraná as function of drainage area.

\begin{tabular}{cccc}
\hline $\begin{array}{c}\text { Area (A) } \\
{\left[\mathbf{k m}^{2}\right]}\end{array}$ & $\begin{array}{c}\text { Number of } \\
\text { gauges }\end{array}$ & $\begin{array}{c}\text { Gauges with } \\
\text { more than 30 } \\
\text { years of data }\end{array}$ & $\begin{array}{c}\text { Gauges with } \\
\text { more than 50 } \\
\text { years of data }\end{array}$ \\
\hline $\mathrm{A} \leq 250$ & 147 & 4 & 2 \\
$250<\mathrm{A} \leq 500$ & 35 & 4 & 1 \\
$500<\mathrm{A} \leq 1000$ & 50 & 8 & 2 \\
$1000<\mathrm{A}$ & 201 & 42 & 21 \\
\hline
\end{tabular}

2017). The Espingarda River basin is part of the middle Iguaçu River basin, characterized by high slopes and rocky valleys (Mine \& Tucci, 2002), giving this region hydrological behavior typical of small river basins, with great flow potential generation - Horton runoff (Schultz, 2017).

For the analysis between the simulated and observed hydrographs we selected 17 events for each basin with rainfall return period between 2 and 50 years and following the criteria: (i) isolated rainfall events when a previous rainfall does not produce runoff; (ii) well-defined hydrographs considering rising, peak, and recession. Pedroso (2019) shows the main characteristics of these events. In the rainfall- runoff modeling based on the statistical analysis of extreme events it is assumed that the return period of the design rain is equal to the hydrograph generated (Canholi, 2005).

The baseflow separation was done using the BFlow software (Eckhardt, 2005). According to Arnold \& Allen (1999), the result of the first filtering pass was used as the Base Flow Index (BFI) of 0.77 for the Pequeno River basin and 0.72 for the Espingarda River basin.

The excess rainfall was estimated by two approaches: (i) the runoff coefficient with constant loss ( $\varphi$ - Phi index method) and (ii) the SCS-CN method. The runoff coefficient was calculated for selected flood hydrographs as the ratio between the runoff volume and total precipitated volume. For the SCS-CN method we adapted maps of soil type and land use (Instituto de Terras, Cartografia e Geologia do Paraná, 2008, 2001), validating or slightly modifying it from Google Earth $®$ images to consider the anthropic interventions presents since the 1980s. We classified the land use in agriculture, forest, and edifications. For both basins, the forest and agriculture features were predominant as presented in Figure 1.

The $\mathrm{CN}$ parameter ranges between 0 and 100 as a function of soil type, land use, and soil moisture. As the scale of our map of land use was not able to infer on specific land use conditions, we used maximum and minimum values of $\mathrm{CN}$ for each soil type class and calculated the overall $\mathrm{CN}$ value for the basins. Table 3 presents the maximum and minimum values of $\mathrm{CN}$ parameters and related potential maximum retention $(\mathrm{S})$ and initial abstractions (Ia) calculated.

After the calculation of the excess daily rainfall, since we selected isolated rainfall events, it was disaggregated for durations shorter than one day - 24 hours, one hour and 0.1 hour - by the isozones method proposed by Torrico (1974) which is still used nowadays in several engineering projects in Brazil (Basso et al., 2016), despite the existence of updates, since Torrico's methodology is a consolidated reference in this kind of studies. Additionally, according to Basso et al. (2016), if a structure is designed according to the coefficients determined by Torrico (1974) for 1 hour rainfall, the structures would be undersized in the South, Southeast and Northeast regions of Brazil. So, for the purposes of this research, there is no impact on overestimations usually attributed to unit hydrographs. It was used the empirical coefficients of the method for isozone $\mathrm{D}$, in which the basins of this study are located. The number of rainfall blocks was determined by the quotient between the time of concentration and unit rainfall duration, and organized by alternated blocks (Bemfica et al., 2000). Values of the disaggregated rainfall were adjusted to the height-duration curves.

The digital elevation model (DEM) of the Topodata Project, from the National Institute for Space Research (INPE), was used to assess morphometric characteristics. DEM is generated from the Shuttle Radar Topographic Mission data with a spatial resolution of $90 \mathrm{~m}$ (SRTM-90), which is made available by the United States Geological Survey (USGS), and then refined with a spatial resolution of $30 \mathrm{~m}$. The main morphometric characteristics estimated for the basins are shown in Table 4.

To estimate the time of concentration tc, considering the diversity of equations available for the calculation of this parameter, applicable according to the characteristics of the hydrographic basins, three widely used equations were applied Kirpich, Vente Chow and USACE. The maximum and minimum values were considered for basins in the application of each $\mathrm{SUH}$ shown in Table 3.

Three SUH methods where applied: Snyder, SCS. and Clark (Chow et al., 1988). All simulations were carried out with software HEC-HMS v. 4.2.1 from USACE. 


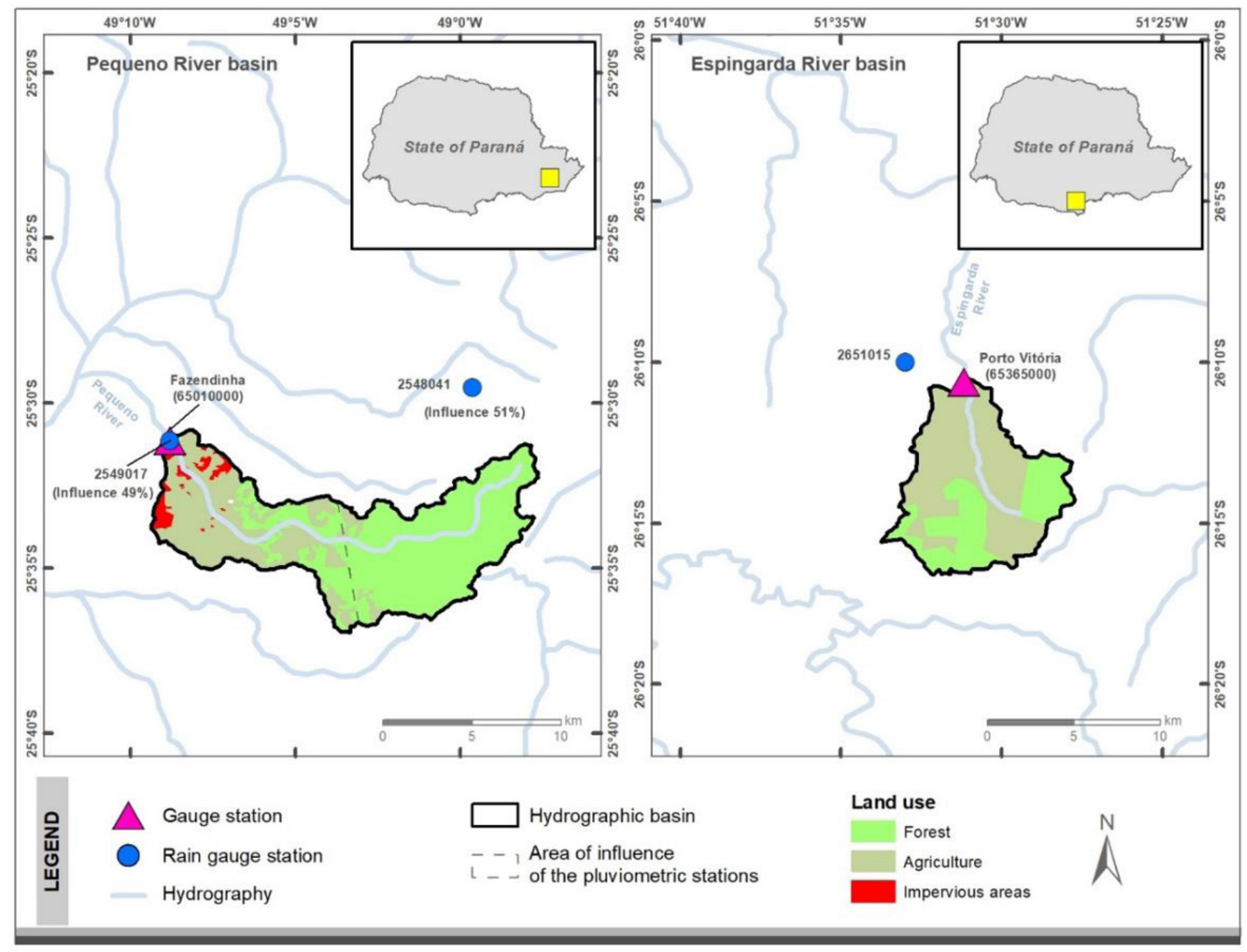

Figure 1. Geographical location of basins, gauge and rain gauge stations used in this study. Maps also show the land use based on Instituto de Terras, Cartografia e Geologia do Paraná (2001) applied to define the CN parameter. The basins are predominantly rural, composed of areas of agriculture and forest. Satellite images were used to identify and validate the classes. Urban residences, industrial zones and rural facilities were classified as impervious areas. Dashed line at Pequeno River basin indicates the zone of influence of the rain gauge stations defined by Thiessen polygons.

Table 3. Maximum and minimum values of the SUH methods parameters, and the CN method for excess rainfall calculation.

\begin{tabular}{|c|c|c|c|c|c|}
\hline \multirow{2}{*}{ Method } & \multirow{2}{*}{ Parameter } & \multicolumn{2}{|c|}{ Pequeno River basin } & \multicolumn{2}{|c|}{ Espingarda River basin } \\
\hline & & $\min$ & $\max$ & $\min$ & $\max$ \\
\hline--- & tc $(\mathrm{h})$ & 5.30 & 6.11 & 1.83 & 2.52 \\
\hline \multirow[t]{3}{*}{$\mathrm{CN}$} & $\mathrm{CN}$ & 54 & 78 & 68 & 84 \\
\hline & $\mathrm{S}(\mathrm{mm})$ & 216 & 72 & 120 & 48 \\
\hline & $\mathrm{Ia}(\mathrm{mm})$ & 43 & 14 & 24 & 10 \\
\hline \multirow[t]{3}{*}{ SUH Snyder } & $\mathrm{Ct}$ & 1.8 & 2.2 & 1.8 & 2.2 \\
\hline & $\mathrm{Cp}$ & 0.56 & 0.69 & 0.56 & 0.69 \\
\hline & tp (h) & 7.85 & 9.60 & 4.62 & 5.65 \\
\hline SUH SCS & tp (min) & 191 & 220 & 65.8 & 91.8 \\
\hline SUH Clark & $\mathrm{K}(\mathrm{h})$ & 3.18 & 3.67 & 1.10 & 1.51 \\
\hline
\end{tabular}

The uncertainties of the method's parameters were defined by maximum and minimum values that produce the higher and lower results of the peak flow. Table 3 shows all the parameters used in the simulations.
We refer to the parameter combination which produces the higher and the lower peak flow as conservative and bold approaches, respectively. The higher value of $\mathrm{CN}$ always produces a higher runoff and is related to a conservative approach. For SCS and 
Table 4. Morphometric characteristics.

\begin{tabular}{ccccc}
\hline Basin & $\begin{array}{c}\text { Length of the main } \\
\text { river }(\mathbf{k m})\end{array}$ & $\begin{array}{c}\text { Length of the main } \\
\text { river to basin centroid } \\
(\mathbf{k m})\end{array}$ & $\begin{array}{c}\text { Altitude variation }(\mathbf{m}) \\
\text { Mean slope of the } \\
\text { main river }(\mathbf{m} / \mathbf{m})\end{array}$ \\
\hline Pequeno River basin & 27 & 13 & 224 & 0.008 \\
Espingarda River basin & 12 & 5 & 314 & 0.026 \\
\hline
\end{tabular}

Clark SUH methods the lower values of $\mathrm{Tp}$ and $\mathrm{K}$ combined with the higher value of $\mathrm{CN}$ produce a conservative result. For Snyder method the higher $\mathrm{CN}$ combined with the lower $\mathrm{Ct}$ e higher $\mathrm{Cp}$ produces the conservative result. The other combination produces the bold result as summarized in Table 5 .

Despite the presence of impervious areas, the lower $\mathrm{CN}$ values for Pequeno River basin are due to the large share area of forest, whereas Espingarda River basin is composed mainly of agricultural areas. The lag time computed by the Snyder methods resulted 2-4 folds the SCS method.

The data consistency analysis was performed according to Lopes et al. (2013) and Agência Nacional de Águas (2011). Rating curves were constructed based on discharge and water level measurements according to Jaccon \& Cudo (1989). The curves should present equally distributed measurement higher and lower than the predicted ones by the curves. Deviations lower than $20 \%$ were considered acceptable. To meet these criteria, curves were constructed for each period minimizing deviations. Figure 2 shows the result and Pedroso (2019) also shows the deviations from measurements for each period.

After the consistency procedure for the measured water level and the rating curve we obtained the flowrate. The deviation of measurements from the curves was on average $9 \%$ and $11 \%$ for Pequeno River and Espingarda River, respectively, considered appropriated by Agência Nacional de Águas (2011). The failures were not filled to avoid introduce more uncertainties. Additional minor details of the consistency analysis are described by Pedroso (2019).

As Girardi et al. (2019) stated, there is a lack of systematic monitoring data in Brazil due to its large dimensions. Most hydrological data in Brazil are measured twice a day, standardized at 7 am and 17 pm (Agência Nacional de Águas, 2016), and we used both. At Pequeno River, we compared the daily mean flow with data from an automatic gauge with a reading every 15 minutes. Figure 3 shows this comparison, with a fitted slope of 1.13. Even though the maximum flow is higher than the average flow, we did not use those data because it was available only after 2013 and just for Pequeno River, so that we worked with the actual availability of existing data for hydrological studies. However, we highlight that our further comparison with observation data is subject to this additional uncertainty in the peak flow observation, not captured by the two daily measurements as reported by Fill \& Steiner (2003).

A double mass curve was built for the rainfall records for checking consistency. A frequency analysis was carried out for each rain gauge station to associate each precipitation to a return period using the Weibull plot position.

For selected events, simulations of SUH were done with the excess rainfall estimated by the $\mathrm{CN}$ method and calculated from the runoff coefficient. The results were presented for peak flow in terms of an estimation ratio of simulated and observed
Table 5. Parameter's combinations of conservative and bold approaches.

\begin{tabular}{|c|c|c|c|c|c|}
\hline \multirow{2}{*}{ Result } & \multirow{2}{*}{$\mathrm{CN}$} & \multirow{2}{*}{$\begin{array}{c}\text { SCS } \\
\text { tp }\end{array}$} & \multicolumn{2}{|c|}{ Snyder } & \multirow{2}{*}{$\frac{\text { Clark }}{\mathrm{K}}$} \\
\hline & & & $\mathrm{Ct}$ & $\mathrm{Cp}$ & \\
\hline Conservative & Max & Min & Min & Max & Min \\
\hline Bold & Min & Max & Max & Min & Max \\
\hline
\end{tabular}

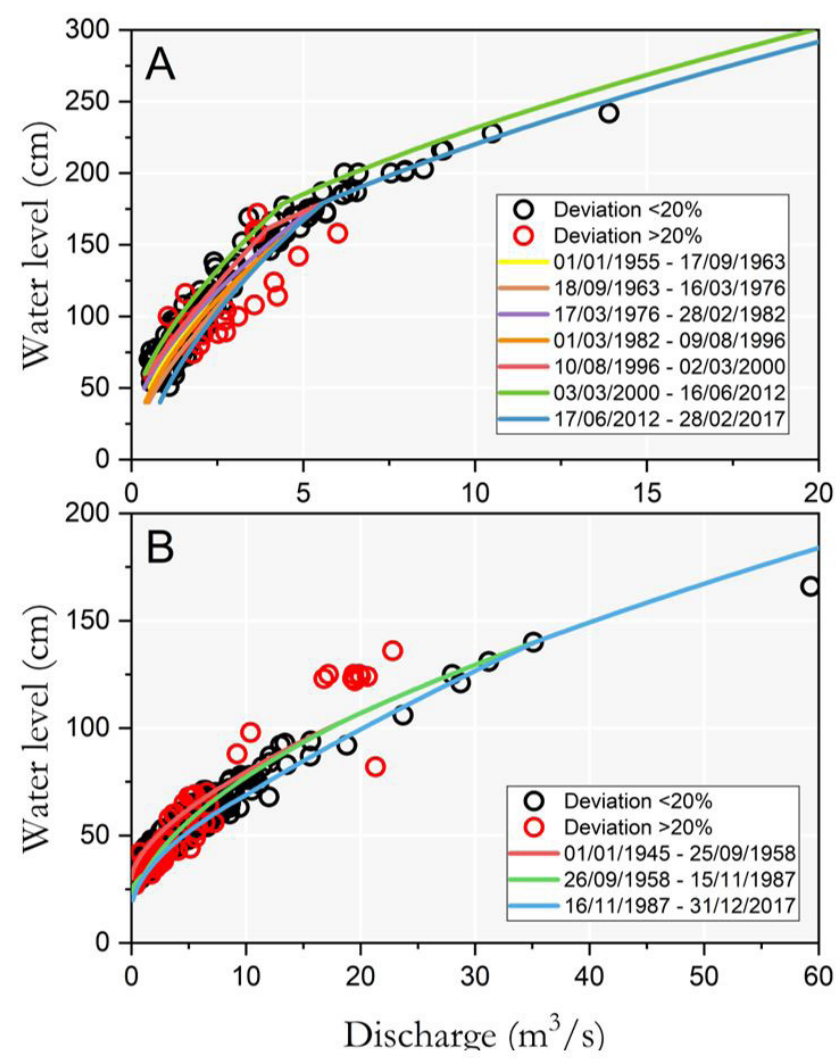

Figure 2. Rating curves for Pequeno River (A) and Espingarda River (B). Measured data which represent deviations from the interpolated rating curve higher than $20 \%$ were highlighted. Rating curves were valid for different periods.

values. A value higher than unitary means that simulated peak flow is higher than the observed, representing an overestimation. A value lower than unitary means an underestimation.

\section{RESULTS AND DISCUSSIONS}

Although it is not the focus to investigate the outliers in Figure 3, we highlight those results validate the use of daily data for the analyzes as the relative error are about $10 \%$. However, it is 
an aspect to be considered as a source of uncertainty since there are some instantaneous flows up to $60 \%$ greater than the average daily flows. This finding reveals the need for additional future research for small basins to assess the real relation between them.

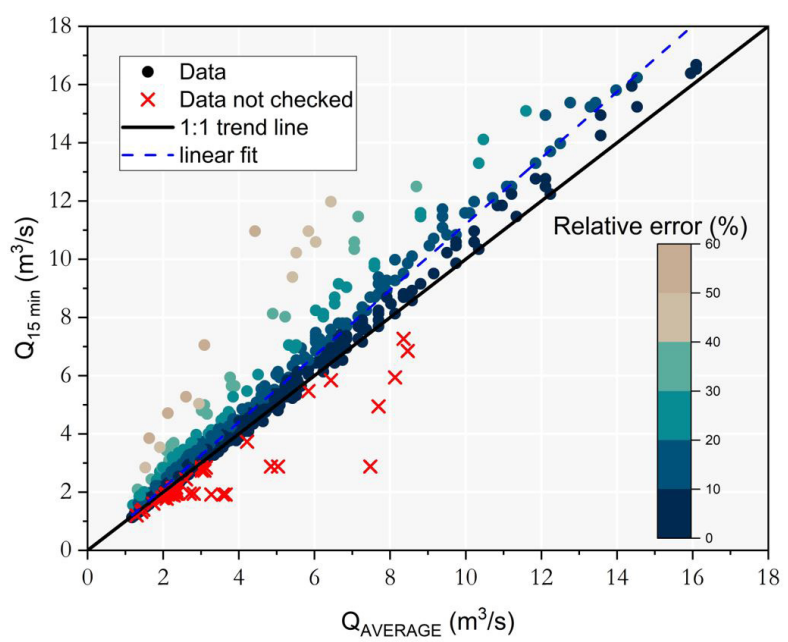

Figure 3. Comparison between average daily flow and maximum daily flow from a 15-minute resolution flow series for Pequeno River between 2013-2017. Relative error is shown in the colormap. Red cross data are highlighted as average flow higher than maximum daily flow which is inconsistent and will not be explorer herein.
Figures 4 and 5 shows the runoff hydrograph comparison of SUH simulations and observations. The envelope curves of SUH do not represent the measurements in terms of the hydrograph's features as rising, recession, peak flow, lag time, and time base. The SUH simulated a faster runoff with higher peak flow and the maximum flows occur on the same day of the event the rainfall, while those observed, especially for the Pequeno River basin, present the peak flows after the second day. Typically, for the Pequeno River basin (Figure 4), the observations showed a time base of 5-6 days due to Dunne runoff while the SUH returned 1 day for SCS and Clark, and 3 days for the Snyder method. Pequeno River basin behaves as a Dunne runoff with high water storage and slow flow due to slope and soil characteristics (Schechi et al., 2013). Similarly, for the Espingarda River basin (Figure 5), the observations showed a time base of 4-6 days, slightly smaller than Pequeno River due to Horton runoff, while the SUH returned 1 day for SCS and Clark, and 2 days for the Snyder method. It is not possible to state the peak time to compare with the SUH simulations because the systematic time step of measurement flow (water level measurement) is about $12 \mathrm{~h}$ ( 7 am and $5 \mathrm{pm}$ from conventional gauge stations in Brazil).

For all return periods, the SCS method simulated the higher peak flows and the Snyder method the lower ones. In general, Clark method simulations were closer to the SCS method.

Figure 4 and 5 compared the observed and simulated peak flows. In general, all SUH produced higher peak flows. For the
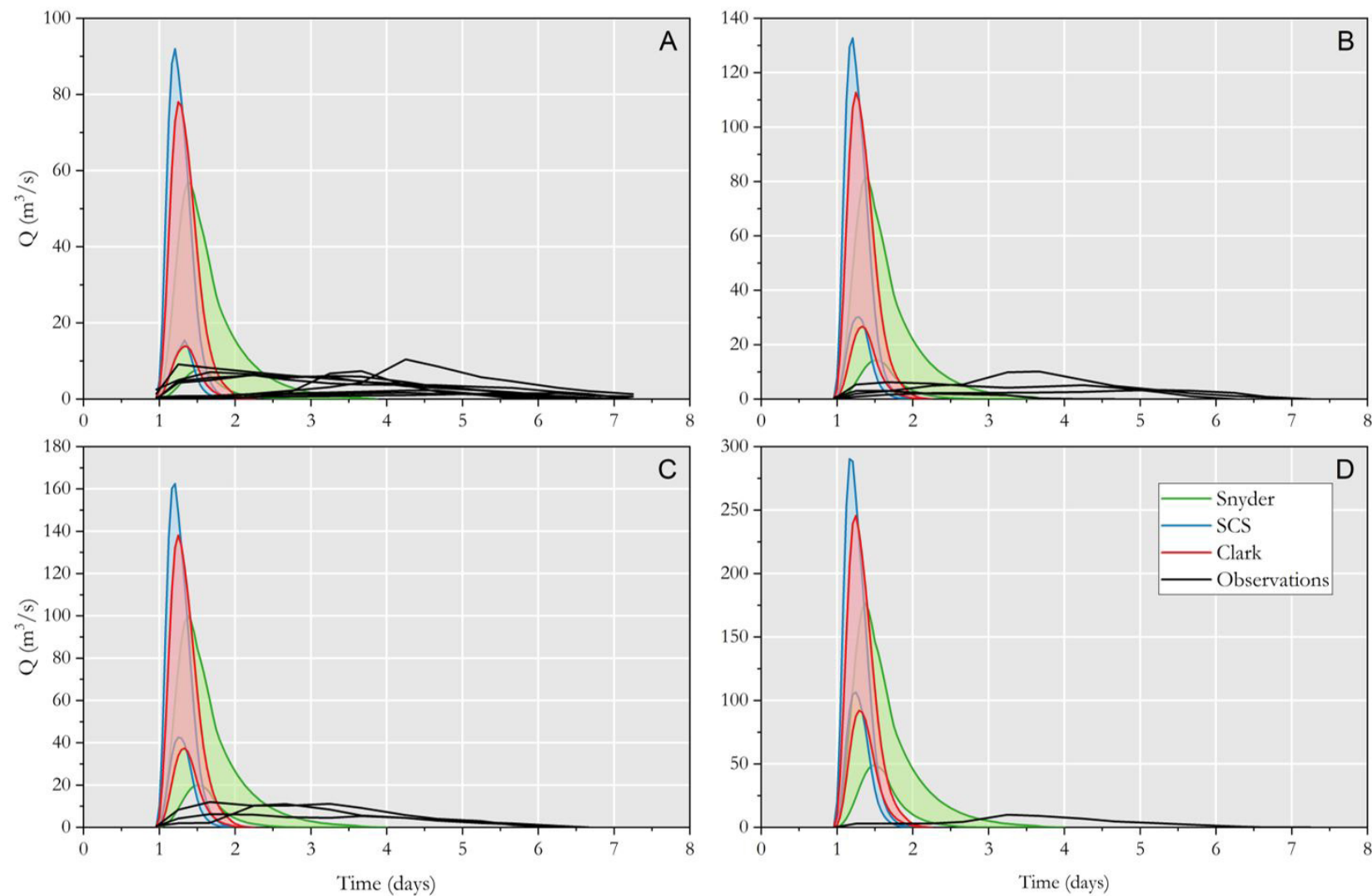

Figure 4. Observed runoff hydrographs and SUH for the Pequeno River basin. SUH was shown as envelope bounding curves from all simulations (according to parameters from Table 5) for each rainfall return period. (A) $\mathrm{T}=2$ years; (B) $\mathrm{T}=5$ years; (C) $\mathrm{T}=10$ years; (D) $\mathrm{T}=50$ years. 

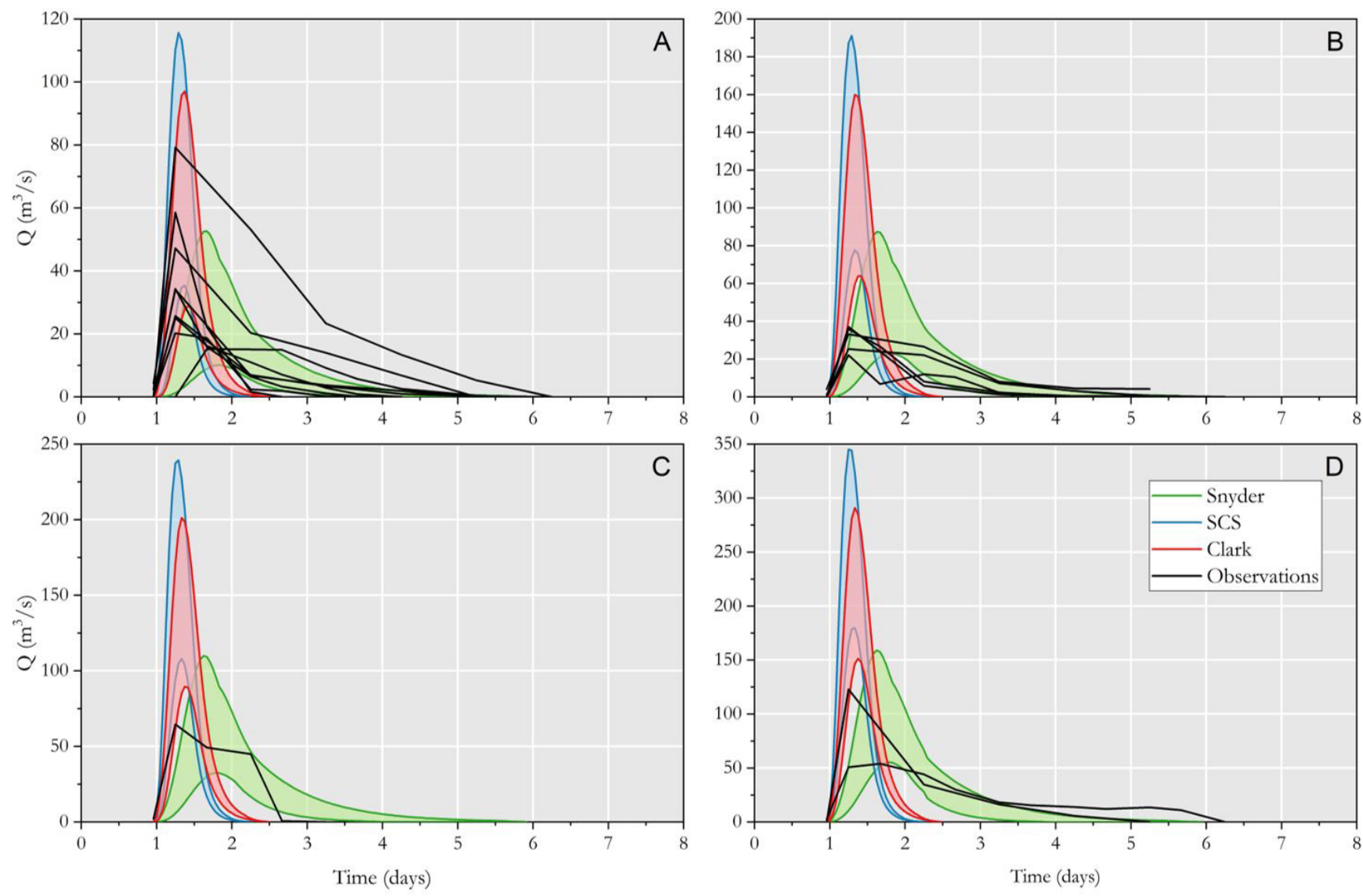

Figure 5. Observed runoff hydrographs and SUH for the Espingarda River basin. SUH was shown as envelope bounding curves from all simulations (according to parameters from Table 5) for each rainfall return period. (A) $\mathrm{T}=2$ years; (B) $\mathrm{T}=5$ years; (C) $\mathrm{T}=10$ years; (D) $\mathrm{T}=50$ years.

Pequeno River basin, only the Snyder method produced peak flows lower than observations, and only for two events with $\mathrm{T}=2$ years.

From the events shown, it is evident that, in practice, a design rainfall with a certain return period does not result in a flow of the same return period, since the highest observed flows are associated with different return time of rainfall. This stems from the non-linearity of the rainfall-runoff ratio, since the flows come from much more complex processes and depend not only on climatic factors, but on the combination of the different characteristics of the basin, such as geomorphological structure and drainage system, not considered in the simplest SUH models.

Figure 6 shows the peak flow estimation ratio for all SUH. It is clearly seen that there is mostly an overestimation of the peak flow, up to 60 folds the measured flow for the Pequeno River. Comparing the conservative to the bold results, even the bold approach overestimates the peak flow, in most of the events. The bold setup parameters where sufficiently conservative considering the peak flow as a design flow. Figure 6 also highlights how SUH changes strongly variability among closer return periods (and consequently rainfalls). The SCS method produced higher peak flows, followed by the Clark method, and the Snyder method shows the lower results.

The Espingarda river (Figure 7C and 7D) shows a similar pattern as the Pequeno river, however, the excess rainfall is generally underestimated for conservative and bold parameters setup. Even the SUH simulation with a lower runoff resulted in generally overestimated peak flow. Since all HUS methods assume Horton runoff premise and the results analysis was based on the comparison of observed and simulated data, Snyder's method shows the best results (peak flow ratio close to 1). For the bold parameter setup, the Snyder method underestimate the peak flow, while Clark and SCS method do for some events.

Despite the uncertainty of the excess rainfall method estimation, the SUH shows a systematic overestimation of the peak flow. The overestimation occurs even for simulated excess rainfall lower than the measured $\left(\mathrm{Pe}_{\mathrm{SUH}} / \mathrm{Pe} \varphi<1\right)$. In this context, the rainfall excess calculation from $\mathrm{CN}$, which is usually applied with SUH, increases deviations in peak flow. Additionally, the standard initial abstraction, fixed as 0.2 of the potential maximum retention, may not be representative for those watershed and other value could be fitted as proposed by Valle Junior et al. (2019), Costa et al. (2019), and Durán-Barroso et al. (2017).

The higher drainage area, lower slope, low flow, and high storage capacity of soils (Schechi et al., 2013), suggest the Dunnian surface flow (Loewen \& Pinheiro, 2017) is dominant in the Pequeno river, resulting in the worst agreement between measurements and simulations. The SUH is based on Hortonian overland generation 


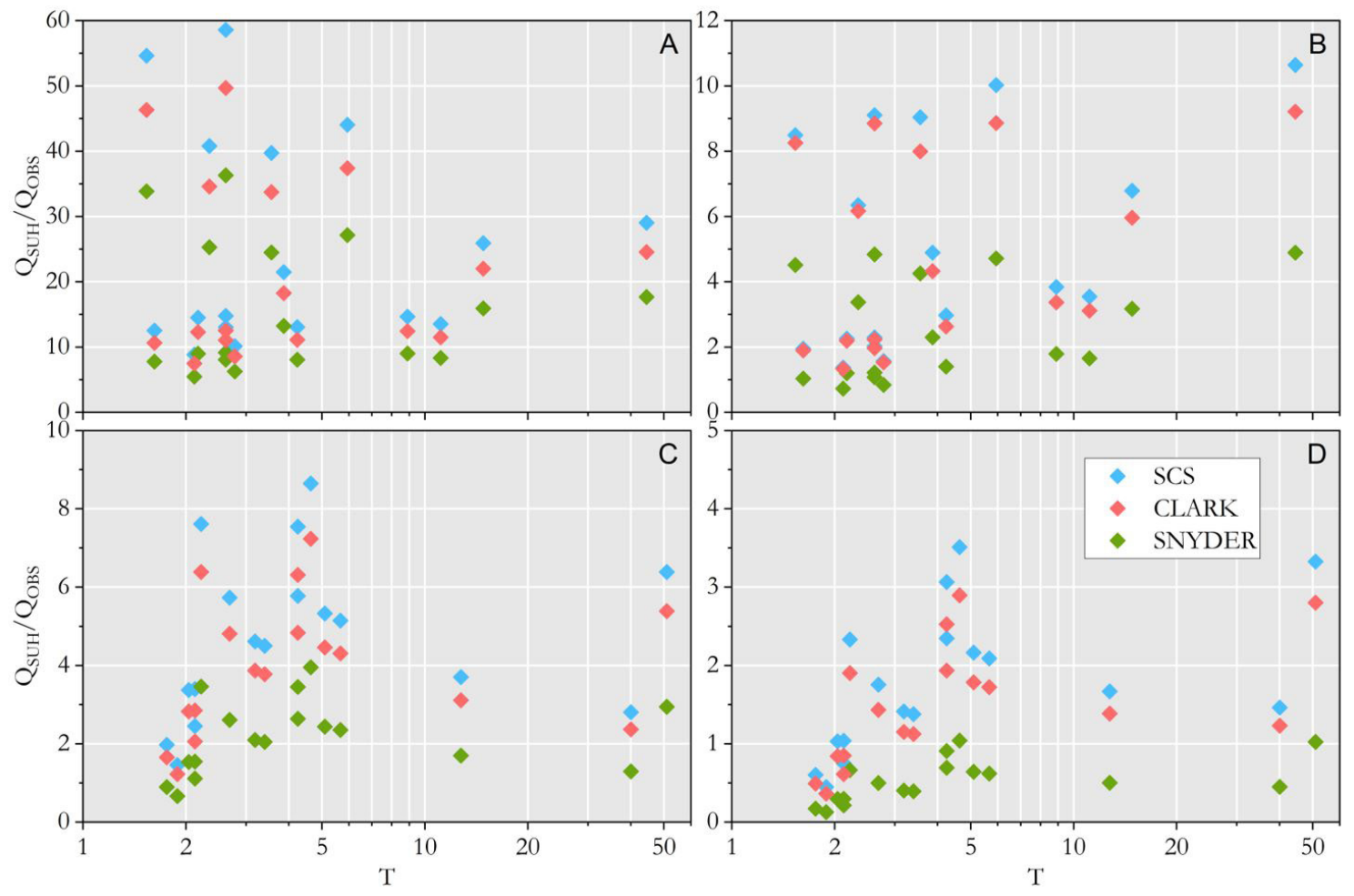

Figure 6. Simulated from SUH and observed ratio of peak flow $\left(\mathrm{Q}_{\mathrm{SUH}} / \mathrm{Q}_{\mathrm{OBS}}\right)$ as function of return period $(\mathrm{T})$ and the three $\mathrm{SUH}$ methods. The lower case OBS means observations and SUH the simulated flows. The excess rainfall was estimated from CN parameter. (A) Conservative result of Pequeno River basin; (B) Bold result of Pequeno River basin gauge; (C) Conservative result of Espingarda River basin; (D) Bold result of Espingarda River basin. Note the different vertical scales.

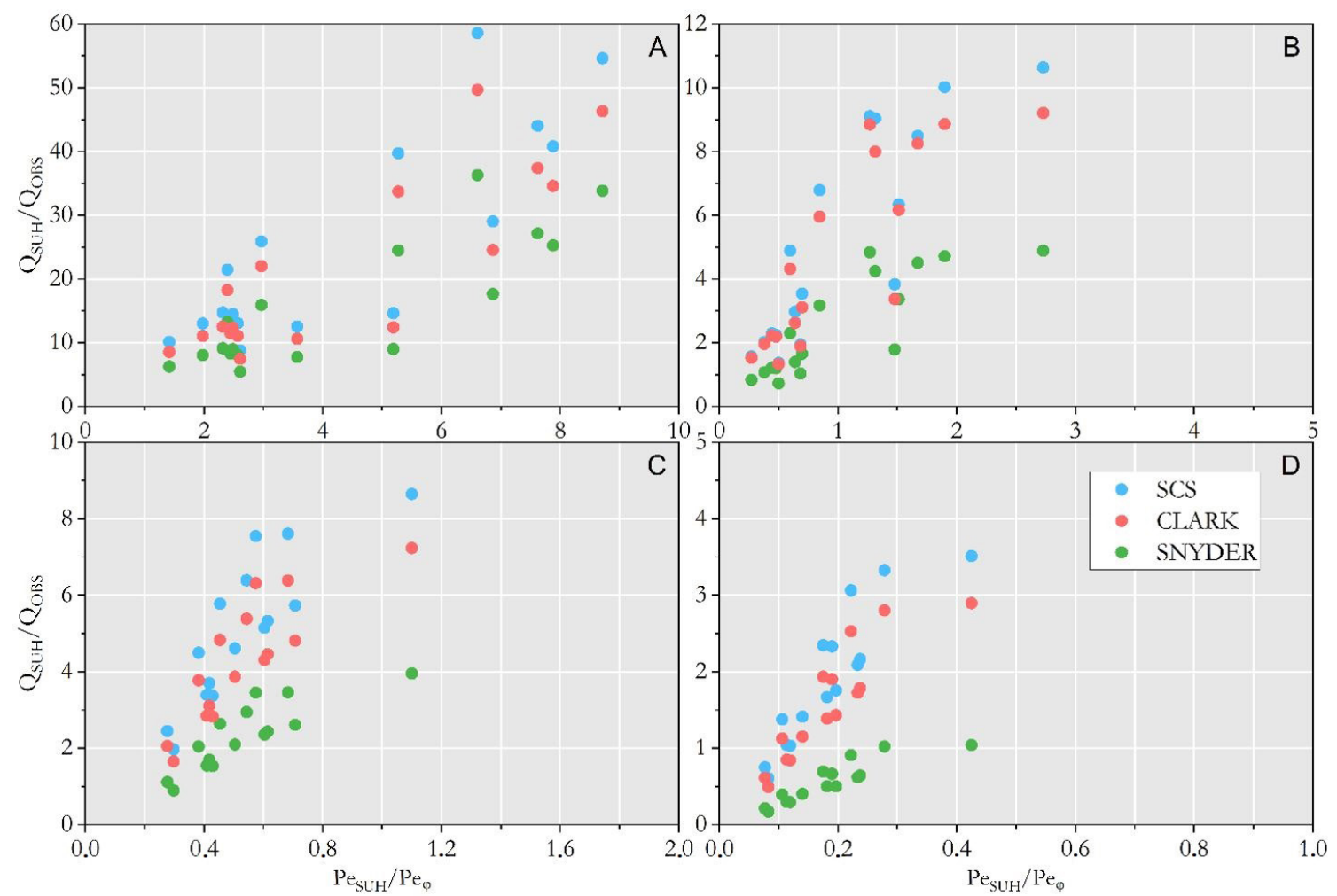

Figure 7. Simulated from SUH and observed ratio of peak flow $\left(\mathrm{Q}_{\mathrm{SUH}} / \mathrm{Q}_{\mathrm{OBS}}\right)$ as function of the ratio between $\mathrm{Pe}_{\mathrm{SUH}} / \mathrm{Pe} \varphi$ and the three SUH methods. (A) Conservative result of Pequeno River basin; (B) Bold result of Pequeno River basin gauge; (C) Conservative result of Espingarda River basin; (D) Bold result of Espingarda River basin. Note the different vertical scales. 
process, which highlights the careful application of SUH, especially considering a large overestimation for design flows.

Figure 8 shows the estimation ratio of peak flow considering the SUH simulation with the excess rainfall computed from measured data (see Pedroso (2019)) for details in obtaining excess rainfall computed from flowrate measurements). For Pequeno River it represented a decrease of the peak flow estimation ratio related to a general overestimation of the excess rainfall (Figures 7A and 7B) because the $\varphi$ coefficient was able to consider Dunne runoff, with higher storage. For Espingarda River the estimation ratio is close to the $\mathrm{CN}$ method for the conservative approach. However, all SUH simulations with conservative and bold parameter setups produced a peak flow estimation ratio higher than 1 , indicating an overestimation.

Contrasting Figure 8 and Figure 7 indicate the model uncertainties since the simulations were done with the excess rainfall computed from measured data.

Table 6 summarizes the ranges of the peak flow estimation ratio for all those scenarios. We found it only for a bold parameter setup and most likely for the Snyder method. For a bold parameter setup, Clark and SCS method generally overestimated the peak flow for Espingarda River. Large overestimation, for all SUH methods, independent of the parameter's setup, can be expected when applied for basins with Dunnian-based runoff generation, as reported for Pequeno River.

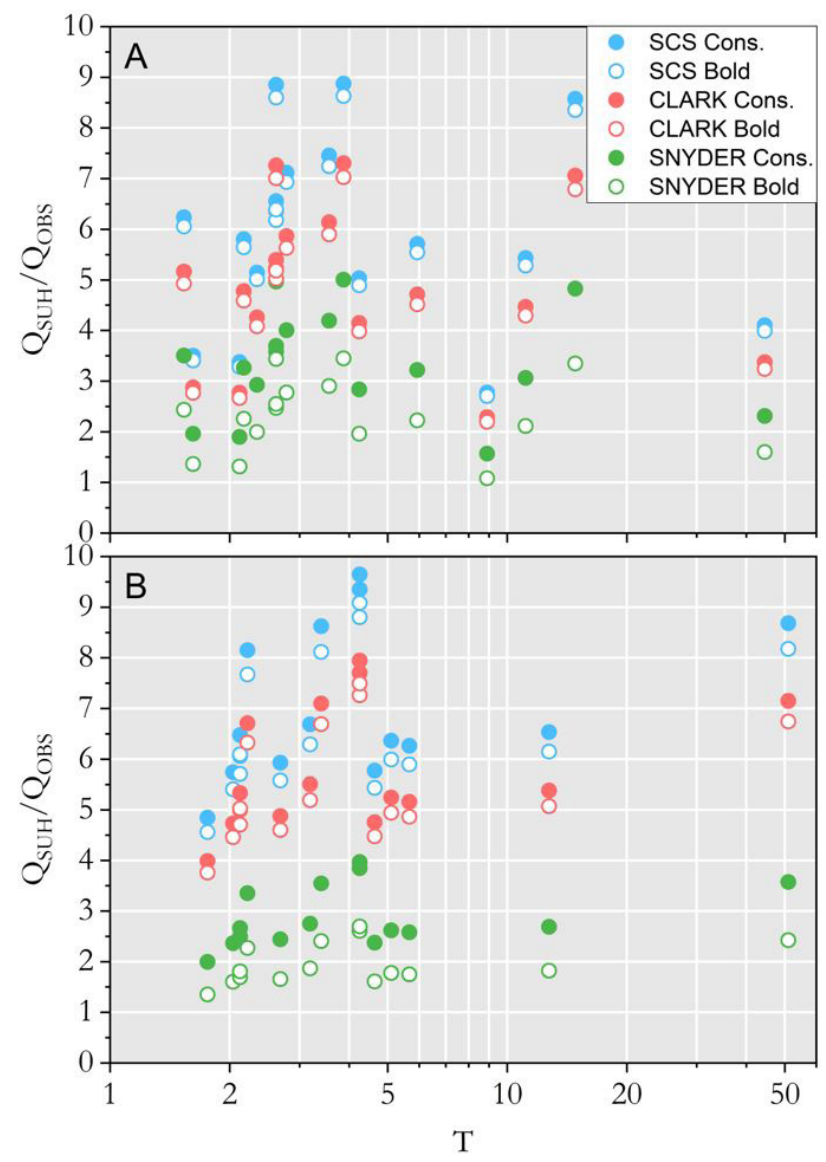

Figure 8. Simulated and observed ratio of peak flow as function of return period, for excess rainfall computed from measurements. (A) Pequeno River basin; (B) Espingarda River basin.
Figure 9 compares data for the normalized simulated peak flow for SUH simulated with excess rainfall from the SCS method and the $\varphi$-index method. Results are presented for both conservative and bold sets of model parameters. Data above the 1:1 line indicates the peak flow simulated with the excess rainfall computed from the SCS is higher than the simulation with the observed excess rainfall. Reciprocally, data below the 1:1 line indicates the opposite. The bold parameter setup reduced the peak flow. For the Pequeno River basin (Figure 9A) the bold parameter setup resulted in peak flow in the same order for both excess rainfall input. For the Espingarda River basin (Figure 9B) the peak flow simulated from the SCS excess rainfall is lower than the simulation with the $\varphi$-index rainfall input. This is mainly due to an underestimation of the excess rainfall as shown in Figures $7 \mathrm{C}$ and $7 \mathrm{D}$.

The peak flow is in general overestimated. The excess rainfall is overestimated for the Pequeno River basin (Figure 7A and 7B) and underestimated for the Espingarda River basin (Figure 7C and 7D). However, when running with the observed excess rainfall the peak flow overestimation is of the same order for both rivers (Figure 8). It could indicate the SUH suffers the same problems

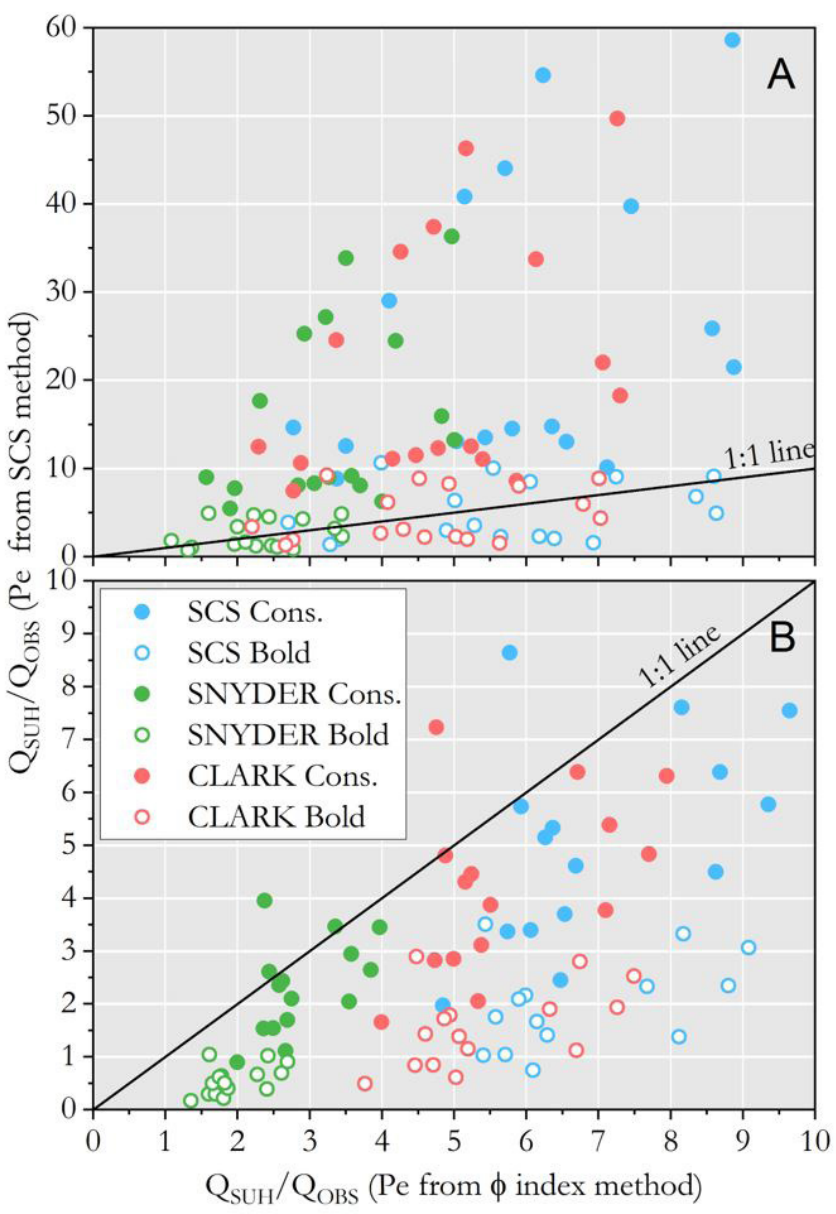

Figure 9. Simulated and observed ratio of peak flow $\left(\mathrm{Q}_{\mathrm{suH}} /\right.$ $\mathrm{Q}_{\mathrm{OBS}}$ ) for excess rainfall computed form SCS method (data from Figures 4, 5, 6 and 7) versus the peak flow ratio computed from the excess rainfall determined by the index $\varphi$ method (data from Figure 8). (A) Pequeno River basin; (B) Espingarda River basin. 
Table 6. Peak flow estimation ratio $\left(\mathrm{Q}_{\mathrm{SHU}} / \mathrm{Q}_{\mathrm{OBS}}\right)$ ranges for $\mathrm{SUH}$ simulation with excess rainfall computed from the SCS-CN method and from runoff measurements by $\varphi$ index method.

\begin{tabular}{ccccc}
\hline SUH & $\begin{array}{c}\text { Excess } \\
\text { rainfall }\end{array}$ & Parameter & $\begin{array}{c}\text { Pequeno } \\
\text { River } \\
\text { basin }\end{array}$ & $\begin{array}{c}\text { Espingarda } \\
\text { River } \\
\text { basin }\end{array}$ \\
\hline SCS & CN & Conserv. & $8.82-58.6$ & $1.46-8.64$ \\
& & Bold & $1.37-10.6$ & $0.45-3.51$ \\
& $\varphi$ & Conserv. & $2.78-8.87$ & $4.85-9.65$ \\
Clark & CN & Bold & $2.70-8.63$ & $4.56-9.08$ \\
& & Conserv. & $7.48-49.7$ & $1.22-7.23$ \\
& $\varphi$ & Bold & $1.33-9.21$ & $0.36-2.90$ \\
Snyder & & Conserv. & $2.29-7.30$ & $3.99-7.94$ \\
& & Bold & $2.20-7.03$ & $3.76-7.49$ \\
& & Conserv. & $5.47-36.3$ & $0.66-3.95$ \\
& $\varphi$ & Bold & $0.73-4.89$ & $0.13-1.04$ \\
& & Conserv. & $1.57-5.00$ & $1.99-3.97$ \\
& & Bold & $1.08-3.45$ & $1.35-2.69$ \\
\hline
\end{tabular}

of overestimation for Horton and Dunne runoff generation. However, for Pequeno River, the hydrograph's features as rising, recession, peak flow, lag time, and time base are not well represented (Figure 4). Additionally, usually, the SUH is applied for a basin with no data, so there is not possible to obtain excess rainfall and it should be estimated. One way to do it is by the SCS-CN method as shown here. In this case, the Pequeno River basin shows a higher peak flow overestimation compared to the Espingarda River basin. We highlight the use of a bold parameter set up to avoid an even higher overestimation of the peak flow, which could be especially higher as shown for the Pequeno River basin.

A bunch of research found different overestimation of the peak flow with a maximum reported up to 7 times (Brunner et al., 2018; Cunha et al., 2015; Hoffmeister \& Weisman, 1977; Singh et al., 2014; Steinmetz et al. 2019; Tucci, 1998; Thorvat \& Patel, 2016; Zakizadeh \& Malekinezhad, 2015;). We highlight the definition of bold and conservative combination of parameters which produced as output, respectively, the lower and higher peak flows. This produced the higher possible range of estimation factor, based on literature parameters, as reported in Table 6 . In this case, the high overestimation factor is consistent to the conservative approach for both basins. It is important to notice that for the bold set of parameters, the estimation factor is in the range of those reported in the literature, even producing underestimation. Additionally, the Dunnian flow generation process of the Pequeno River basin produced the higher simulated peak flow overestimation.

The accomplishment measured by the peak flow estimation factor is also sensible to the time scale of the monitoring data used from daily rainfall and the streamflow time scale of about 12 hours. Figure 3 suggests differences lower than 50\% between the higher time resolution maximum flow and the daily average flow for the Pequeno River basin. Thus, considering the streamflow the computed estimation factor is the higher value possible.

\section{CONCLUSIONS}

The performance of SUH in the two basins studied where consistent to similar applications where we verified a general overestimation of the peak flow.
The SCS method produced an overestimation of the peak flow up to 60 folds the observed runoff for Pequeno River basin and 10 folds for Espingarda River basin, considering a conservative estimation of the excess rainfall, leading to higher peak flows. The Snyder method showed the best results comparing to Clark and SCS methods.

The SUH application with the excess rainfall computed from runoff suggest the SUH method were essentially conservative, especially the SCS and Clark methods because they systematically overestimate the peak flow. A bold approach of parameters setup is sufficiently conservative in terms of peak flow result for SCS and Clark methods, since it showed lower errors compared to measurements. Snyder's method with a bold parameter setup could lead to an underestimation.

The lower drainage area basin (Espingarda River) showed the best results, probably associated with the best fit to the SUH premises of uniform rainfall. On the other hand, Pequeno river suggested a Dunne runoff generation process showed worst results considering the peak flow overestimation for all methods.

Finally, the application of SUH in hydrological studies in ungauged basins should be carefully considering the potential overestimation of design flows. Geological studies could reveal indications of a Dunne runoff generation, as in the case of the Pequeno River, lead to overestimation.

The flowrate and rainfall data uncertainties were reduced by a deep consistency analysis. Other uncertainties are due to the model and its parameters. The uncertainties of the SUH models were evidenced by running them with the excess rainfall computed from measurements. In this case the SUH generally overestimate the peak flow even for a bold parameter setup.

Among the SUH parameters, the most sensible was the excess rainfall computed by the SCS-CN method. The overestimation, for all methods, is strongly driven by the excess rainfall estimation. We do recommend considering a bold parameter setup.

Design methods are expected to produce overestimations and this study aims to analyze some of the uncertainties of their application, to provide guidance on how to best use them. This study does not analyze input data uncertainties. The results of this study should be tested in a larger number of river basins before making a generalization.

Future research on evaluation of uncertainties of SUH application can be the use of individual satellite images for each rainfall event to better characterize the $\mathrm{CN}$ value as it possible change seasonally and over years. Additionally, basins that have smaller monitoring scales with compatible temporal resolution with the application basins.

\section{ACKNOWLEDGEMENTS}

The authors would like to thank Geovana Thais Colombo for the English checking and RHA Engenharia e Consultoria SS Ltda who promote the first author during her master with a special schedule and professional flexibilization. The manuscript was improved by valuable comments of anonymous reviewers.

\section{REFERENCES}

Agência Nacional de Águas - ANA. (2011). Diretrizes e análises recomendadas para a consistência de dados fluviométricos. Brasília: ANA, SGH. 
Agência Nacional de Águas - ANA. (2016). Sistemas de informação na gestão de águas: conhecer para decidir (Vol. 8). Brasília: ANA.

Arnold, J. G., \& Allen, P. M. (1999). Automated methods for estimating baseflow and ground water recharge from streamflow records 1. Journal of the American Water Resources Association, 35(2), 411-424. http://dx.doi.org/10.1111/j.1752-1688.1999.tb03599.x.

Basso, R. E., Allasia, D. G., Tassi, R., \& Pickbrenner, K. (2016). Revisão das isozonas de chuvas intensas do Brasil. Engenharia Sanitaria e Ambiental, 21(4), 635-641. http://dx.doi.org/10.1590/ s1413-41522016133691.

Bemfica, D. C., Goldenfum, J. A., \& da Silveira, A. L. L. (2000). Análise da aplicabilidade de padrões de chuva de projeto a Porto Alegre. Revista Brasileira de Recursos Hidricos, 5(4), 5-16. http:// dx.doi.org/10.21168/rbrh.v5n4.p5-16.

Bhunya, P. K., Panda, S. N., \& Goel, M. K. (2011). Synthetic unit hydrograph methods: a critical review. The Open Hydrology Journal, 5(1), 1-8. http://dx.doi.org/10.2174/1874378101105010001.

Bras, R. L. (1990). Hydrology: an introduction to bydrologic science. Boston: Addison-Wesley.

Brunner, M. I., Sikorska, A. E., Furrer, R., \& Favre, A. C. (2018). Uncertainty assessment of synthetic design hydrographs for gauged and ungauged catchments. Water Resources Research, 54(3), 1493-1512. http://dx.doi.org/10.1002/2017WR021129.

Canholi, A. P. (2005). Drenagem urbana e controle de enchentes. São Paulo: Oficina de Textos.

Chow, V. T., Maidment, D. R., \& Mays, L. W. (1988). Applied bydrology. New York: McGraw-Hill.

Costa, F. F., Paz, A. R., \& Piccilli, D. G. A. (2019). Modified NRCS-CN-TUH methods for distributed rainfall-runoff modeling. Revista Brasileira de Recursos Hídricos, 24, e21. http:// dx.doi.org/10.1590/2318-0331.241920180104.

Cunha, S. F., Silva, F., Mota, T. U., \& Pinheiro, M. (2015). Avaliação da acurácia dos métodos do SCS para cálculo de precipitação efetiva e hidrogramas de cheia. Revista Brasileira de Recursos Hídricos, 20(4), 837-848. http://dx.doi.org/10.21168/rbrh.v20n4.p837-848.

Durán-Barroso, P., González, J., \& Valdés, J. B. (2017). Sources of uncertainty in the NRCS CN model: recognition and solutions. Hydrological Processes, 31(22), 3898-3906. http://dx.doi.org/10.1002/ hyp. 11305.

Eckhardt, K. (2005). How to construct recursive digital filters for baseflow separation. Hydrological Processes: An International Journal, 19(2), 507-515. http://dx.doi.org/10.1002/hyp.5675.

Fill, H. D., \& Steiner, A. A. (2003). Estimativa do hidrograma instantâneo e da vazão máxima de enchentes a partir de vazões médias diárias. Revista Brasileira de Recursos Hídricos, 8(3), 17-26.
Girardi, R., Pinheiro, A., \& Venzon, P. (2019). Parâmetros de qualidade de água de rios e efluentes presentes em monitoramentos não sistemáticos. REGA, 16, e2. http://dx.doi.org/10.21168/ rega.v16e2.

Hoffmeister, G., \& Weisman, R. N. (1977). Accuracy of synthetic hydrographs derived from representative basin. Hydrological Sciences Journal, 22(2), 297-312. http://dx.doi.org/10.1080/02626667709491719.

Hrachowitz, M., Savenije, H. H. G., Blöschl, G., McDonnell, J. J., Sivapalan, M., Pomeroy, J. W., Arheimer, B., Blume, T., Clark, M. P., Ehret, U., Fenicia, F., Freer, J. E., Gelfan, A., Gupta, H. V., Hughes, D. A., Hut, R. W., Montanari, A., Pande, S., Tetzlaff, D., Troch, P. A., Uhlenbrook, S., Wagener, T., Winsemius, H. C., Woods, R. A., Zehe, E., \& Cudennec, C. (2013). A decade of Predictions in Ungauged Basins (PUB): a review. Hydrological Sciences Journal, 58(6), 1198-1255. http://dx.doi.org/10.1080/02 626667.2013 .803183 .

Instituto de Terras, Cartografia e Geologia do Paraná - ITCG. (2008) Mapa de solos. Curitiba.

Instituto de Terras, Cartografia e Geologia do Paraná - ITCG. (2001). Mapa de uso do solo - 2001/2002. Curitiba.

Jaccon, G., \& Cudo, K. J. (1989). Curva-chave: análise e traçado. Brasília: DNAEE.

Loewen, A. R., \& Pinheiro, A. (2017). Overland flow generation mechanisms in the Concórdia River basin, in southern Brazil. Revista Brasileira de Recursos Hídricos, 22(0), e4. http://dx.doi. org/10.1590/2318-0331.011716026.

Lopes, W. T. A., Lemos, G. M., Silva, M. C. A. M., Piscoya, R. C. C. C., \& Gomes, A. O. (2013). Sistema para análise de dados hidrológicos - SIADH. In Anais do XX Simpósio Brasileiro de Recursos Hídricos. Bento Gonçalves: ABRH.

Mine, M. R., \& Tucci, C. E. (2002). Gerenciamento da produção de energia e controle de inundação: Foz do Areia no rio Iguaçu. Revista Brasileira de Recursos Hídricos, 7(3), 85-107. http://dx.doi. org/10.21168/rbrh.v7n3.p85-107.

Pedroso, A. (2019). Análise da incerteza de bidrogramas unitários sintéticos na estimativa da vaz̃ão de projeto em duas bacias hidrográficas pequenas (Dissertação de mestrado). Universidade Federal do Paraná, Curitiba.

Raudkivi, A. J. (1979). Hydrology: an advanced introduction to bydrological processes and modeling. Oxford: Pergamon Press.

Schechi, R. G., Bianchi, R. D. C., Guimarães, R. Z., \& Rizzi, N. E. (2013). Avaliação da capacidade potencial de armazenamento de água na bacia hidrográfica do Rio Pequeno, São José dos Pinhais, PR. Floresta, 43(2), 205-214. http://dx.doi.org/10.5380/ rf.v43i2.26530. 
Schultz, G. B. (2017). Conectividade hidrossedimentológica em bacias experimentais embutidas (Tese de doutorado). Curitiba: Universidade Federal do Paraná.

Schulz, K., Burgholzer, R., Klotz, D., Wesemann, J., \& Herrnegger, M. (2018). Demonstrating the unit hydrograph and flow routing processes involving active student participation: a university lecture experiment. Hydrology and Earth System Sciences, 22(4), 2607-2613. http://dx.doi.org/10.5194/hess-22-2607-2018.

Silveira, A. L. L. D. (2016). Fator de pico para hidrogramas unitários sintéticos triangulares. Revista Brasileira de Recursos Hidricos, 21(1), 46-52. http://dx.doi.org/10.21168/rbrh.v21n1.p46-52.

Singh, P. K., Mishra, S. K., \& Jain, M. K. (2014). A review of the synthetic unit hydrograph: from the empirical UH to advanced geomorphological methods. Hydrological Sciences Journal, 59(2), 239261. http://dx.doi.org/10.1080/02626667.2013.870664.

Steinmetz, A. A., Beskow, S., Terra, F. da S., Nunes, M. C. M., Vargas, M. M., \& Horn, J. F. C. (2019). Spatial discretization influence on flood modeling using unit hydrograph theory. Revista Brasileira de Recursos Hídricos, 24, e16. http://dx.doi.org/10.1590/23180331.241920180143.

Thorvat, A. R., \& Patel, J. N. (2016). Empirical approach to develop synthetic unit hydrographs for ungauged Dhamani basin, Maharashtra (India). International Journal of Hydrology Science and Technology, 6(3), 266-284. http:/ /dx.doi.org/10.1504/IJHST.2016.077396.

Torrico, J. J. T. (1974). Práticas hidrológicas. Rio de Janeiro: Transcon.

Tucci, C. E. M. (1998). Modelos hidrológicos (1. ed.). Porto Alegre: UFRGS/ABRH.
Valle Junior, L. C. G., Rodrigues, D. B. B., \& Oliveira, P. T. S. (2019). Initial abstraction ratio and Curve Number estimation using rainfall and runoff data from a tropical watershed. Revista Brasileira de Recursos Hidricos, 24, e5. http:/ /dx.doi.org/10.1590/23180331.241920170199.

Wagener, T., Wheater, H., \& Gupta, H. V. (2004). Rainfall-runoff modelling in ganged and unganged catchments. London: Imperial College Press. http://dx.doi.org/10.1142/p335.

Zakizadeh, F., \& Malekinezhad, H. (2015). Comparison of methods for estimation of flood hydrograph characteristics. Russian Meteorology and Hydrology, 40(12), 828-837. http://dx.doi. org/10.3103/S1068373915120080.

\section{Authors contributions}

Andreia Pedroso: Methodology desing, Writing - Original Draft, data curation, investigation, visualization, formal analysis.

Michael Mannich: paper conceptualization, methodology desing, writing - original draft, writing - review \& editing, visualization, formal analysis, supervision.

Editor-in-Chief: Adilson Pinheiro

Associated Editor: Priscilla Macedo Moura 